Article

\title{
Improving Health Professionals' Involvement Whilst Sustaining Work-Life Balance: Evidence from an Empirical Analysis
}

\author{
Rocco Palumbo \\ Department of Management \& Law, University of Rome "Tor Vergata", Via Columbia, no. 2, 00133 Rome, Italy; \\ rocco.palumbo@uniroma2.it
}

Received: 27 October 2020; Accepted: 6 November 2020; Published: 9 November 2020

check for updates

\begin{abstract}
Most sustainability studies applied to healthcare primarily focus on external viability. In particular, they look at the ability of healthcare institutions to establish an economic, environmental, social, and political consonance with their context. Conversely, limited attention has been paid to issues related to internal sustainability. The article discusses health professionals' involvement as a human resource management practice which contributes to the viability of healthcare organizations. A sequential mediation analysis was designed to shed light on the effects of employees' involvement on work-life balance, which is an essential ingredient of the recipe for internal sustainability. The study findings suggest that health professionals' involvement may determine an intensification and an extensification of work efforts, which undermine their work-life balance. Nevertheless, the implications of employees' involvement on work-life balance are positively and significantly mediated by supportive relationships at work and positive organizational climate. From this standpoint, health professionals' involvement may act as an effective strategy to enhance the internal sustainability of health care organizations if matched with better relationships with supervisors and improved organizational climate. Whilst calling for further research to enlighten issues and challenges related to internal sustainability, the article stresses that health professionals' involvement should be paired with an improvement of the organizational climate to contribute to an increased viability of health care institutions.
\end{abstract}

Keywords: work-life balance; employee involvement; healthcare; internal sustainability; organizational climate

\section{Introduction}

The purpose of integrating sustainability into the functioning of health care institutions can be largely retrieved in theory and in practice [1,2]. However, scholars quarrel over the contextualization of this concept to health care [3]. It has been claimed that sustainability has been usually exploited as "...a plot device that helps to steer the story in a particular direction, 'black-boxing' certain aspects of context and emphasizing others" [4] p. 297. Sticking to a resource allocation and finance-based perspective [5], sustainability has been primarily understood as the health systems' capability of maintaining, in the long term, an appropriate health services delivery capacity [6]. This involves finding timely financial and economic resources to deal with the evolving epidemiologic, demographic, social, technological, and institutional challenges that imperil the functioning of healthcare organizations [7]. Alongside the financial and economic dimensions, several other features characterize the application of the sustainability idea to healthcare. Firstly, environmental sustainability is associated with the aim of curbing the footprint on the environment produced by healthcare institutions due to the huge amount of energy consumption and waste generation related to health services delivery [8]. Secondly, social 
sustainability concerns the health care institutions' ability to make a conscious and responsible use of available resources, ensuring fairness, equity, and appropriateness in the access to care and upholding the welfare of both current and future generations [9]. Thirdly, political sustainability encompasses the ability of health care organizations to meet the fast-changing expectations of the community, which are embedded into existing legal-political frameworks. This allows them to achieve a larger institutional legitimacy and an increased political support [10].

These conceptualizations concern macro level issues and emphasize the policy and strategic relevance of sustainability for health care institutions [11]. Nevertheless, literature has claimed that, in addition to policy and strategy making, everyday management practices are essential to ensure the viability of healthcare organizations [12]. Actually, the economic, environmental, social, and political sustainability of healthcare institutions basically relies on their organizational capability to mobilize and manage available inputs and resources to accomplish their mission within the constraints determined by existing structures, cultures, and processes [13]. From this point of view, the internal sustainability of healthcare institutions should be carefully investigated, with a specific focus on their ability to arrange proper organizational schemes and management approaches which underpin the effectiveness of internal processes and prevent unforeseen issues from impairing the healthcare institutions' capability to produce a valuable service for the community [14]. Inter alia, the achievement of internal organizational sustainability calls for the design and the implementation of sound human resource management practices, which permit health care institutions to establish a productive and sustainable workplace. This is a precondition for the attainment of external sustainability, enabling health care organizations to fulfill their institutional goals, preserving the integrity of their organizational climate and maintaining their inner equilibria [15].

Health professionals' involvement has been identified as a requisite for achieving sustainability in healthcare, implying a greater participation of employees in the managerial dynamics of healthcare organizations and sustaining a stronger organizational commitment [16]. In general terms, employees' involvement entails the arrangement of tailored human resource management practices that are intended to support the employees' participation in work-related decision making and to empower them to contribute to the enhancement of their work environment [17]. Previous research has investigated the manifold implications of employees' involvement on internal sustainability, emphasizing its positive effect [18]. Whilst employees' involvement has been generally found to trigger increased job satisfaction, which nurtures a greater devotion to work [19], scholars disagree over the implications of employees' involvement on work-life balance [20], which is a core component of internal sustainability for healthcare organizations [21,22]. Work-life balance engenders the ability of employees to achieve equity and effectiveness in managing multiple roles across the private sphere of life and the working environment [23]. On the one hand, employees' involvement fosters positive sensations about work, which may entail a greater willingness to put an increased effort into achieving organizational goals, without endangering the perceived work-life balance [24]. On the other hand, employees' involvement may trigger a process of work intensification and extensification, thus increasing the work-related stress of employees and undermining their ability to achieve a balance between work and life [25].

In line with these introductory notes, scholars have maintained the need for balancing employees' involvement with tailored interventions directed at sustaining their organizational commitment, without compromising their ability to handle the work-life interplay and, therefore, avoiding a worsening of their work-related well-being [26]. Such interventions include the amelioration of the social climate within healthcare organizations, which has been found to be associated with a greater employees' participation into organizational dynamics [27], as well as the establishment of a supportive and empowering working environment, which is thought to prevent the backlash of employees' involvement on work intensification and extensification [28]. In light of these arguments, the article attempted to advance what we currently know about the implications of employees' involvement in promoting internal organizational sustainability. More specifically, it examined the implications of health professionals' involvement on individual work-life balance, including in the analysis the 
mediating role of supportive relationships at work and positive organizational climate. In particular, the following research questions inspired this research:

R.Q. 1: Does employees' involvement affect the work-life balance of employees?

R.Q. 2: Does a supportive organizational climate mediate the implications of employees' involvement on individual work-life balance?

R.Q. 3: Which kind of managerial interventions are needed for fostering the contribution of employees' involvement on healthcare organizations' sustainability?

An empirical, quantitative research design was arranged to provide an answer to these research questions. The remaining part of the article is organized as follows. Section 2 articulates the conceptual framework against which this empirical research was conceived. Moreover, it proposes the research hypotheses, which steered data analysis and elaboration. Section 3 illustrates the study design, providing some details about the statistical approach that was used to collect evidence about the contribution of employees' involvement to the achievement of internal organizational sustainability. Section 4 reports the study findings, providing the output of research hypotheses testing. Section 5 critically discusses the study results, summarizing the conceptual and practical implications of this research. Lastly, Section 6 ends up the paper, emphasizing the value of this study and envisioning some avenues for further developments.

\section{Theoretical Framework and Research Hypotheses}

Employees' involvement has been largely associated with the achievement of internal organizational sustainability. Alongside being a prerequisite to organizational excellence [29], it has been found to pave the way for increased organizational effectiveness, sustaining the workforce morale and boosting organizational performances [30]. As previously anticipated, involvement implies that employees: (1) are empowered and enabled to make (or, at least, to participate in) decisions about their working environment and to act on such decisions; (2) have the opportunity to update their knowledge and to apply their own ideas at work; and (3) are engaged in enhancing the effectiveness of their work [31]. From this standpoint, the success of employees' involvement initiatives relies on the willingness of the workforce to embrace the opportunities for involvement, escaping organizational cynicism and disengagement [32].

Previous research has stressed that the active involvement of employees triggers greater job satisfaction and stimulates their commitment to the accomplishment of the organizational goals [33]. However, a critical perspective holds that employees' involvement can be improperly used by manager to get a greater control over the workforce, which is subject to an extensification and an intensification of work [34]. In line with these arguments, employees' involvement practices can be handled as purposeful management expedients, which are ultimately intended to extract a greater effort from the workforce [35]. This is consistent with the adoption of a patchwork approach in the implementation of employees' involvement programs [36], which are implicitly directed at increasing the workforce organizational commitment, without necessarily enacting an empowerment process [37]. In sum, employee involvement initiatives have been also depicted as a revised version of Fordism [38], which may bring with itself an overidentification of employees with managers and, consequently, an intensification of work [39]. In turn, this may impair the employees' ability to handle the work-life interface. In fact, greater availability for work produced by employee involvement interventions may determine a greater risk of contamination between private life and working commitments, leading to work to life and life to work conflicts [40]. This is especially true when professionals operating in the public sector-which is usually the case of health professionals-are concerned, since they are particularly exposed to the intensification of work determined by involvement in work-related practices [41,42]. Drawing on these points, it was assumed that: 
Hypothesis 1 (H1). Employees' involvement may have some negative effects on the ability of the workforce to handle the work-life interface.

It is worth noting that previous research has reported that managers may resist and challenge organizational initiatives intended to empower employees, in an attempt to preserve their control over organizational dynamics and to minimize threats to self-interest [43]. Notwithstanding, implying a sharing of decision making responsibilities, as well as of risks and gains that are related to organizational decisions, employees' involvement may also foster an improvement of the relationships between employees and supervisors [44]. Similarly, employee involvement interventions may trigger a development of interdependencies in the workplace, entailing an improvement of the organizational climate [45]. Echoing these points, an association between employees' involvement initiatives and positive employee-manager relationships has been highlighted in literature [46]. Employee involvement creates a sense of engagement in the manager-employee relationship, which contributes in sustaining the organizational performances [47].

The active involvement of employees may also determine some positive implications on the social climate within the organization [48]. In fact, an interplay has been argued to exist between employees' involvement and the degree of fairness, collaboration, and trust in the workplace [49], which engenders a better satisfaction of employees with their work [50]. At the same time, the supervisors' ability to establish sound and meaningful relationships with the employees may entail an enhancement of the organizational climate [51], fostering an increased fairness in the workplace and determining positive exchanges amongst employees [52]. Hence, synthesizing these considerations, it was hypothesized that:

Hypothesis 2 (H2). Employees' involvement enhances the employee-manager relationships, boosting the establishment of positive exchanges;

Hypothesis 3 (H3). Employees' involvement contributes to the amelioration of the organizational climate, sustaining a sense of fairness, trust, and collaboration in the workplace;

Hypothesis 4 (H4). Better employee-manager relationships foster an improvement of the organizational climate, paving the way for an aggregating working environment.

Misalignment in the relationship between employees and managers [53] and abusive supervision exercised by managers over employees [54] have been found to have a negative effect on employees' work-life balance. Conversely, a positive relationship with managers based on trust building has been claimed to lead to an enhancement of the quality of work for employees [55], thus leading to positive implications on their work-related happiness [56]. Better employee-manager relationships enhance the authenticity and the meaningfulness of managerial activities [57]. This reduces the risks of work exhaustion perceived by employees, concurring in increasing their ability to manage the work-life interplay [58]. Organizational climate is thought to contribute in the achievement of a work-life balance for employees, since it improves the working conditions of employees [59]. Indeed, high levels of trust, collaboration, and reciprocity in the workplace may determine an increase in employees' ability to manage the work-life interplay [60]. In addition, scholars have shown that sound employee-manager relations trigger an improvement of the organizational climate [61], which, in turn, has positive effects on individual work-life balance [62]. Therefore, it was maintained that:

Hypothesis 5 (H5). Better employee-manager relationships contribute to the improvement of the employees' perceptions about their ability to manage the work-life interplay;

Hypothesis 6 (H6). Positive organizational climate sustains the employees' perception of work-life balance. 
Taking stock of these arguments, alongside investigating the direct effects of employees' involvement on work-life balance, its indirect effects should be unraveled. On the one hand, stimulating an amelioration of the employee-manager relationship and nurturing an improvement of organizational performances, management practices intended to promote employees' involvement may indirectly contribute to the enhancement of individual work-life balance [63]. On the other hand, increasing the soundness and the meaningfulness of the organizational climate, practices intended to support employees' involvement may reduce the perception of life-to-work and work-to-life struggles, thus indirectly contributing to the improvement of individual well-being [64]. From this standpoint, it was argued that:

Hypothesis 7 (H7). Employee-manager relationships mediate the implications of employees' involvement on work-life balance, so that the employees' perceptions to manage the work-life interplay are better;

Hypothesis 8 (H8). A positive organizational climate mediates the implications of employees' involvement on work-life balance, so that the employees' perceptions of managing the work-life interplay are better;

Hypothesis 9 (H9). Employee-manager relationships and organizational climate serially mediate the implications of employees' involvement on work-life balance, so that the employees' perceptions of managing the work-life interplay are better.

Figure 1 synthesizes the theoretical framework against which this study was conceived. Also, it points out the hypothesized relationships between the main constructs involved in the analysis.

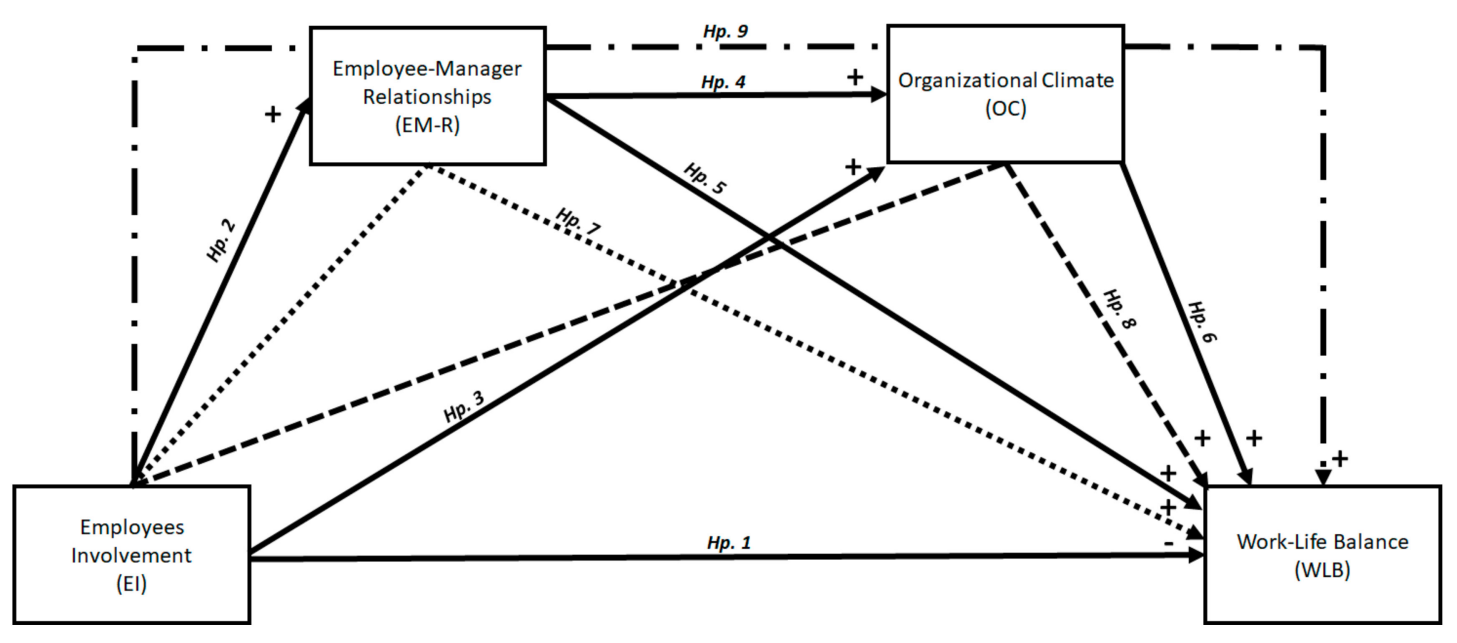

Figure 1. A graphical representation of the theoretical framework.

\section{Methodology}

\subsection{Research Strategy}

A serial mediation analysis was designed to shed light onto the direct and indirect effects of employees' involvement initiatives on individual work-life balance. This study design allowed researchers to collect some evidence on the direct implications of employees' involvement on their ability to manage the work-life interface. At the same time, it allowed us to obtain some insights into the mediating role played by employee-manager relationships and organizational climate. Therefore, the serial mediation analysis was consistent with the contents of the 9 research hypotheses that inspired this study. The statistical approach proposed by Hayes [65], based on bootstrap sampling and estimations and on OLS regression-based path analysis, was undertaken. Figure 2 shows a graphical 
representation of the statistical diagram that was employed in this study. All elaborations were run through the IBM Statistical Package for the Social Science (SPSS ${ }^{\circledR}$, version 24, Berlin, Germany).

Secondary data were accessed from the Eurofound's European Workplace Conditions Survey (EWCS). The EWCS is a periodic, pan-European survey, which is intended to assess working conditions of employees and self-employed people across Europe. Alongside the 27 Member Countries of the EU, Albania, Norway, Montenegro, Serbia, Switzerland, the former Yugoslav Republic of Macedonia, the United Kingdom, and Turkey participate in the EWCS. The latest EWCS survey was queried to collect data. More specifically, the sixth wave of the EWCS was accessed for the purpose of this research. Fieldwork activities related to the collection of original data kicked off in 2015. All the residents of the participating countries aged 15 or older and in employment at the time of the survey were eligible to participate in the EWCS. A multi-stage, stratified, random sampling technique was adopted to select respondents. Face-to-face interviews delivered at the respondents' home were realized to collect data. The final sample consisted of 43,850 European employees, whose geographical distribution reflected the population size of the participating countries. For the purpose of this empirical research, only people who reported to be employed at the time of the survey and who stated to be either health professionals or health associate professionals according to the International Standard Classification of Occupations (ISCO) were included in the analysis. The subsample that was involved in this research contained 1928 health professionals. Additional details about the sample are reported below in Section 3.4.

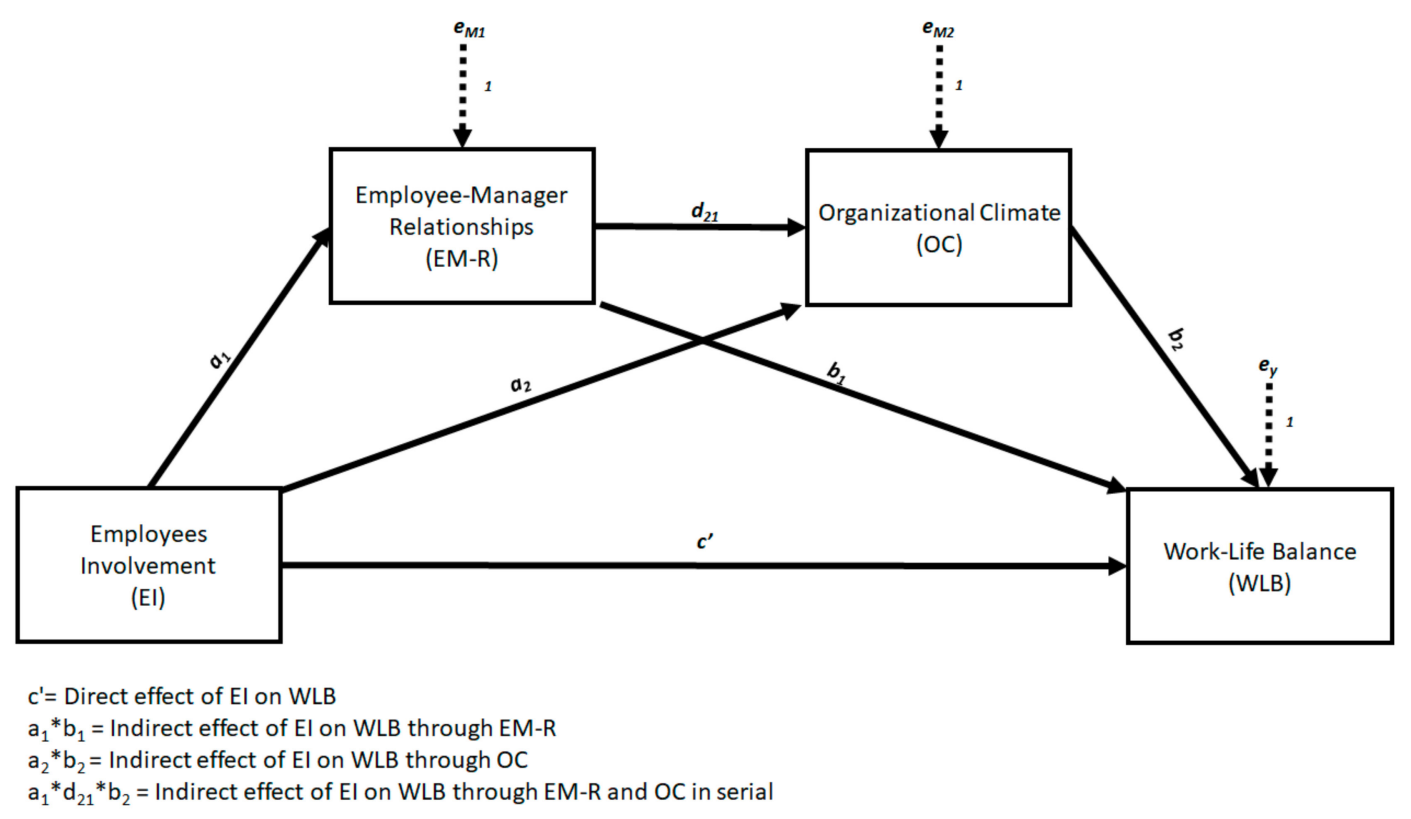

Figure 2. The statistical diagram used for empirical analysis.

\subsection{Data and Variables}

A multi-item approach was used to assess the degree of employees' involvement in organizational and management dynamics related to their work (EI). In particular, EI was derived from 5 items, which accounted for the respondents' participation in organizational decisions related to their work, their ability to apply ideas and creativity at work, their engagement in goal setting, and their involvement in the design and implementation of work-improvement processes. An additive scheme was used to synthetize the items and to gauge the degree of employees' involvement. EI was a continuous variable, ranging from 1 (lowest level of respondents' involvement in organizational dynamics) to 5 (highest level of employees' involvement). EI had a good internal reliability, as assessed by the Cronbach's alpha and by the composite reliability index [66] $(\alpha=0.77 ; C R=0.83)$.

Work-life balance (WLB) was assessed in a similar way, embracing a multi-item model. Both experiences of work-to-life and life-to-work conflicts were taken into consideration to measure the 
respondents' ability to manage the work-life interplay. WLB resulted from the aggregation of 5 items, which focused on the contamination of work into daily private activities and on the overlapping of burdens related to social life and family affairs with work commitments. An additive model was used to compound the 5 items in a single measure. WLB was a continuous variable, which ranged between 1 (lowest level of work-life balance) and 5 (highest level of work-life balance). It showed a good internal reliability $(\alpha=0.75 ; C R=0.82)$.

Employee-manager relationships (EM-R) were assessed through six items, which focused on the respondents' self-evaluation of their work-related exchanges with supervisors. Respondents were asked to appraise their relationships with their supervisors in terms of trust, respect, support, collaboration, feedback, and empowerment. Once again, an aggregative scheme was used to measure EM-R. This construct was a continuous variable, ranging from 1 (worst level of employee-manager relations) to 5 (best level of employee-manager relations). EM-R disclosed a good internal reliability score $(\alpha=0.90 ; \mathrm{CR}=0.89)$.

Lastly, organizational climate (OC) was assessed in light of the features of the social environment that hosted the everyday working activities of respondents. Health prodessionals self-assessed the levels of fairness, loyalty, cooperation, friendliness, justice, and unity in the workplace. Going more into details, OC derived from the aggregation of 6 items, which were combined according to an additive model. It was a continuous variable, ranging from 1 (poorest organizational climate) to 5 (richest organizational climate). OC had a good internal reliability $(\alpha=0.85 ; C R=0.83)$. Table 1 reports an overview of the measures that were used in this empirical study.

Table 1. The measures included in empirical analysis.

\begin{tabular}{|c|c|c|c|c|c|c|c|}
\hline Variable (ID) & Definition & $\begin{array}{l}\text { Illustrative } \\
\text { Item }\end{array}$ & $\begin{array}{l}\text { Type of } \\
\text { Variable }\end{array}$ & $\begin{array}{l}\text { No. of } \\
\text { Items }\end{array}$ & Scale/Code & CR & $\alpha$ \\
\hline \multicolumn{8}{|c|}{ Independent variable } \\
\hline $\begin{array}{l}\text { Employees' } \\
\text { Involvement } \\
\text { (EI) }\end{array}$ & $\begin{array}{l}\text { Active participation } \\
\text { of employees in } \\
\text { organizational and } \\
\text { managerial } \\
\text { dynamics related to } \\
\text { their work }\end{array}$ & $\begin{array}{c}\text { You are } \\
\text { involved in } \\
\text { improving the } \\
\text { work } \\
\text { organization or } \\
\text { work processes } \\
\text { of your } \\
\text { department or } \\
\text { organization? }\end{array}$ & Continuous & 5 & $\begin{array}{c}1=\text { lowest level of } \\
\text { employees' } \\
\text { involvement } \\
5=\text { highest level } \\
\text { of employees' } \\
\text { involvement }\end{array}$ & 0.83 & 0.77 \\
\hline \multicolumn{8}{|c|}{ Dependent variable } \\
\hline $\begin{array}{c}\text { Work-Life } \\
\text { Balance } \\
\text { (WLB) }\end{array}$ & $\begin{array}{l}\text { Employees' } \\
\text { self-rated ability to } \\
\text { handle the } \\
\text { work-life interface }\end{array}$ & $\begin{array}{c}\text { How often have } \\
\text { you kept } \\
\text { worrying about } \\
\text { work when you } \\
\text { were not } \\
\text { working? }\end{array}$ & Continuous & 5 & $\begin{array}{c}1=\text { Lowest level } \\
\text { of work-life } \\
\text { balance } \\
5=\text { Highest level } \\
\text { of work-life } \\
\text { balance }\end{array}$ & 0.82 & 0.75 \\
\hline \multicolumn{8}{|c|}{ Mediating variables } \\
\hline $\begin{array}{l}\text { Employee- } \\
\text { Manager } \\
\text { Relationships } \\
\text { (EM-R) }\end{array}$ & $\begin{array}{l}\text { Employees' } \\
\text { self-rated quality of } \\
\text { relationship with } \\
\text { their direct } \\
\text { supervisor }\end{array}$ & $\begin{array}{l}\text { Your immediate } \\
\text { boss is helpful } \\
\text { in getting the } \\
\text { job done }\end{array}$ & Continuous & 6 & $\begin{array}{l}1=\text { worst level of } \\
\text { employee-manager } \\
\text { relationships } \\
5=\text { best level of } \\
\text { employee-manager } \\
\text { relationships }\end{array}$ & 0.89 & 0.90 \\
\hline $\begin{array}{l}\text { Organizational } \\
\text { Climate } \\
(\mathrm{OC})\end{array}$ & $\begin{array}{l}\text { Quality of the social } \\
\text { environment } \\
\text { hosting the working } \\
\text { activities of } \\
\text { employees }\end{array}$ & $\begin{array}{l}\text { The work is } \\
\text { distributed } \\
\text { fairly }\end{array}$ & Continuous & 6 & $\begin{array}{c}1=\text { Poorest } \\
\text { organizational } \\
\text { climate } \\
5=\text { Richest } \\
\text { organizational } \\
\text { climate }\end{array}$ & 0.83 & 0.85 \\
\hline
\end{tabular}




\subsection{Constructs' Reliability and Consistency}

Several statistical checks were accomplished to get some evidence about the reliability of the study design. An exploratory factor analysis (EFA) was implemented to check the existence of the four underlying constructs depicted above [67]. The EFA stuck to the Kaiser's eigenvalue-greater-than-one rule [68]. The Kaiser-Meyer-Olkin $(\mathrm{KMO})$ test $(\mathrm{KMO}=0.922)$ and the Bartlett's test of sphericity (approx. $\chi^{2}=14,970.88, \mathrm{df}=231$, sig. $=0.000$ ) supported a four-factors model, which, after 5 iterations, had an initial eigenvalue higher than 1 and explained more than $58 \%$ of the total variance. Table 2 shows the varimax rotated factor loadings of the EFA.

Table 2. The outputs of the exploratory factor analysis (EFA).

\begin{tabular}{|c|c|c|c|c|c|c|c|c|c|}
\hline \multicolumn{10}{|c|}{ Total Variance Explained } \\
\hline \multirow{2}{*}{ Components } & \multicolumn{3}{|c|}{ Eigenvalues } & \multicolumn{3}{|c|}{$\begin{array}{l}\text { Extraction Sums of Squared } \\
\text { Loadings }\end{array}$} & \multicolumn{3}{|c|}{$\begin{array}{c}\text { Rotation Sums of Squared } \\
\text { Loadings }\end{array}$} \\
\hline & Total & $\begin{array}{c}\% \text { of } \\
\text { Variance }\end{array}$ & $\begin{array}{c}\text { Cumulative } \\
\%\end{array}$ & Total & $\begin{array}{c}\% \text { of } \\
\text { Variance }\end{array}$ & $\begin{array}{c}\text { Cumulative } \\
\%\end{array}$ & Total & $\begin{array}{c}\% \text { of } \\
\text { Variance }\end{array}$ & $\begin{array}{c}\text { Cumulative } \\
\% \\
\end{array}$ \\
\hline 1 & 7074 & 32,157 & 32,157 & 7074 & 32,157 & 32,157 & 4287 & 19,487 & 19,487 \\
\hline 2 & 2494 & 11,336 & 43,493 & 2494 & 11,336 & 43,493 & 3218 & 14,626 & 34,113 \\
\hline 3 & 1972 & 8963 & 52,455 & 1972 & 8963 & 52,455 & 2726 & 12,392 & 46,505 \\
\hline 4 & 1263 & 5742 & 58,197 & 1263 & 5742 & 58,197 & 2572 & 11,692 & 58,197 \\
\hline 5 & 0968 & 4399 & 62,596 & & & & & & \\
\hline 6 & 0763 & 3469 & 66,064 & & & & & & \\
\hline 7 & 0687 & 3122 & 69,187 & & & & & & \\
\hline 8 & 0625 & 2842 & 72,029 & & & & & & \\
\hline 9 & 0613 & 2787 & 74,816 & & & & & & \\
\hline \multirow[t]{4}{*}{10} & 0564 & 2561 & 77,377 & & & & & & \\
\hline & Rotated C & omponent & Matrix & & & & & & \\
\hline & & Com & ponents & & & & & & \\
\hline & 1 & 2 & 3 & 4 & & & & & \\
\hline EI_1 & 0.105 & 0.037 & 0.707 & 0.036 & & & & & \\
\hline EI_2 & 0.079 & 0.143 & 0.762 & 0.014 & & & & & \\
\hline EI_3 & 0.190 & 0.150 & 0.697 & 0.050 & & & & & \\
\hline EI_4 & 0.134 & 0.089 & 0.753 & 0.010 & & & & & \\
\hline EI_5 & 0.089 & 0.062 & 0.591 & -0.074 & & & & & \\
\hline EM-R_1 & 0.609 & 0.335 & 0.141 & 0.118 & & & & & \\
\hline EM-R_2 & 0.790 & 0.167 & 0.206 & 0.074 & & & & & \\
\hline EM-R_3 & 0.775 & 0.350 & 0.073 & 0.087 & & & & & \\
\hline EM-R_4 & 0.753 & 0.194 & 0.097 & 0.055 & & & & & \\
\hline EM-R_5 & 0.825 & 0.216 & 0.122 & 0.043 & & & & & \\
\hline EM-R_6 & 0.823 & 0.202 & 0.195 & 0.044 & & & & & \\
\hline OC_1 & 0.492 & 0.558 & 0.168 & 0.106 & & & & & \\
\hline OC_2 & 0.202 & 0.721 & 0.089 & 0.084 & & & & & \\
\hline OC_3 & 0.341 & 0.704 & 0.141 & 0.125 & & & & & \\
\hline $\mathrm{OC}_{-} 4$ & 0.238 & 0.722 & 0.082 & 0.147 & & & & & \\
\hline OC_5 & 0.097 & 0.643 & 0.144 & 0.138 & & & & & \\
\hline OC_6 & 0.397 & 0.680 & 0.050 & 0.083 & & & & & \\
\hline WLB_1 & 0.196 & 0.099 & -0.143 & 0.604 & & & & & \\
\hline WLB_2 & 0.096 & 0.092 & 0.079 & 0.670 & & & & & \\
\hline WLB_3 & 0.103 & 0.126 & 0.030 & 0.749 & & & & & \\
\hline WLB_4 & 0.005 & 0.114 & 0.033 & 0.744 & & & & & \\
\hline WLB_5 & -0.072 & 0.057 & -0.002 & 0.720 & & & & & \\
\hline
\end{tabular}

Extraction Method: principal component analysis; rotation method: varimax with Kaiser normalization; rotation converged in 6 iterations.

A confirmatory factor analysis (CFA) was implemented to ensure the reliability and the dependability of the fourfold articulation of the items that were investigated in this empirical analysis [69]. The output of the CFA confirmed the fitness of the four-constructs theoretical model showcased above $\left(\chi^{2}=1245.41, \mathrm{df}=203, p<0.001 ; \mathrm{CFI}=0.940, \mathrm{RMSEA}=0.052\right.$, PClose $=0.162$, $\mathrm{NFI}=0.929, \mathrm{TLI}=0.925)$. To check for common method bias, a common latent factor was included in the CFA [70]. The fits indexed by the model, including the common latent factor, were worse 
compared with the four-factors model $\left(\chi^{2}=1979.90, \mathrm{df}=185, p<0.001 ; \mathrm{CFI}=0.896, \mathrm{RMSEA}=0.071\right.$, PClose $=0.000, \mathrm{NFI}=0.887, \mathrm{TLI}=0.858)$. Moreover, the Harman's one factor test was run. All the items were assumed to load on a single unmeasured common factor. This single factor explained $32.2 \%$ of the total variance, which was significantly less than the $50 \%$ threshold recommended to detect common method variance. These outputs suggested that common method bias was not an issue for this research. The bivariate correlations between the four factors were positive and statistically significant. In all the cases, correlations were lower than 0.5, with the sole exception of EM-R and OC $(\rho=0.67)$. However, the variance inflation factors (VIF) were higher than 1 , ranging from 1.17 and 1.85. Hence, it could be maintained that multicollinearity was not an issue for this research.

\subsection{Sample}

Table 3 includes an overview of the study sample. On the whole, 1928 health professionals and health associate professionals were taken into consideration in the research. On average, they took more than $46 \mathrm{~min}(\sigma=14.36 \mathrm{~min}$ ) to complete the EWCS questionnaire. The respondents represented the main geographical areas of Europe. More than a fifth of health professionals dwelled in Northern Europe (22.5\%). Southern Europe (30.3\%) and Western Europe (28.4\%) were evenly portrayed in the sample. About a fifth of respondents came from Eastern Europe (18.8\%). Women represented the majority of the sample (81.1\%). Average age of respondents was 43 years $(\sigma=11.44$ years). Most of them were born in the same country where they lived and worked at the time of interview (86.8\%). About 1 in 4 respondents had either lower secondary (2.9\%), upper secondary $(26.3 \%)$, or post-secondary education $(9.7 \%)$. A fifth of them accomplished a short-term tertiary education (19.7\%), whilst about a fourth had a bachelor or equivalent university degree (24\%). Less than 1 in 6 health professionals had a masters university degree (14.2\%). Lastly, 62 respondents had a doctorate (3.2\%).

The large majority of the sample had an unlimited term contract (86.5\%). Less than a fourth reported to work part-time (23.9\%). On average, they worked for the organizations in which they were employed at the time of interview for 12 years $(\sigma=10.23$ years), ranging from a minimum of 1 year to a maximum of 50 years. About 2 in 3 health professionals were employed in the public sector $(66.4 \%)$. Large-sized organizations employing 250 people and more covered half of the sample $(47.8 \%)$. A third of respondents worked for medium-sized institutions (34.8\%), whilst less than 1 in 6 health professionals worked for small-sized organizations with less than 10 employees (14.9\%). 
Table 3. The sample sociodemographic attributes $(n=1928)$.

\begin{tabular}{|c|c|c|}
\hline \multirow{2}{*}{ Variable } & \multicolumn{2}{|c|}{ Total } \\
\hline & No. & $\%$ \\
\hline \multicolumn{3}{|c|}{ Gender } \\
\hline Men & 363 & 18.8 \\
\hline Women & 1564 & 81.1 \\
\hline Do not know/Did not answer & 1 & 0.1 \\
\hline \multicolumn{3}{|c|}{ Geographical area } \\
\hline Northern Europe & 433 & 22.5 \\
\hline Western Europe & 547 & 28.4 \\
\hline Southern Europe & 585 & 30.3 \\
\hline Eastern Europe & 363 & 18.8 \\
\hline \multicolumn{3}{|c|}{ Age group } \\
\hline 24 years and below & 76 & 3.9 \\
\hline Between 25 and 34 years & 463 & 24 \\
\hline Between 35 and 44 years & 490 & 25.4 \\
\hline Between 35 and 54 years & 548 & 28.4 \\
\hline Between 55 and 64 years & 325 & 16.9 \\
\hline 65 years and above & 25 & 1.3 \\
\hline Do not know/Did not answer & 1 & 0.1 \\
\hline \multicolumn{3}{|c|}{ Country of birth } \\
\hline Some country of residence & 1673 & 86.8 \\
\hline Foreign country & 247 & 12.8 \\
\hline Do not know/Did not answer & 8 & 0.4 \\
\hline \multicolumn{3}{|c|}{ Education (ISCED) } \\
\hline Lower secondary education & 56 & 2.9 \\
\hline Upper secondary education & 508 & 26.3 \\
\hline Post-secondary education & 187 & 9.7 \\
\hline Short-cycle tertiary education & 379 & 19.7 \\
\hline Bachelor or equivalent & 463 & 24 \\
\hline Master or equivalent & 273 & 14.2 \\
\hline Doctorate or equivalent & 62 & 3.2 \\
\hline \multicolumn{3}{|c|}{ Sector } \\
\hline Public sector & 1281 & 66.4 \\
\hline Private sector & 640 & 33.2 \\
\hline Other & 7 & 0.4 \\
\hline \multicolumn{3}{|c|}{ Type of contract } \\
\hline Unlimited duration contract & 1668 & 10.1 \\
\hline Limited duration contract & 195 & 86.5 \\
\hline Do not know/Did not answer & 65 & 3.4 \\
\hline \multicolumn{3}{|c|}{ Part-time/Full-time } \\
\hline Full-time contract & 1466 & 76 \\
\hline Part-time contract & 461 & 23.9 \\
\hline Do not know/Did not answer & 1 & 0.1 \\
\hline \multicolumn{3}{|c|}{ Organizational age } \\
\hline 1 year and below & 218 & 11.3 \\
\hline Between 2 and 5 years & 442 & 23.9 \\
\hline Between 6 and 10 years & 403 & 20.9 \\
\hline Between 11 and 20 years & 466 & 24.2 \\
\hline 21 years and above & 386 & 20 \\
\hline Do not know/Did not answer & 13 & 0.7 \\
\hline \multicolumn{3}{|c|}{ Organizational dimension (per employees' number) } \\
\hline 9 employees or below & 288 & 14.9 \\
\hline Between 10 and 249 employees & 671 & 34.8 \\
\hline 250 employees and above & 922 & 47.8 \\
\hline Do not know/Did not answer & 47 & 2.5 \\
\hline
\end{tabular}




\section{Findings}

Some descriptive statistics allowed us to get an overview of the working conditions of health professionals and health associate professionals involved in this study. On average, the respondents reported to work $36.6 \mathrm{~h}$ per week $(\sigma=9.88 \mathrm{~h})$. More than half stated that they did not work at night (62.3\%). Conversely, a third pointed out that they worked at least once per month between 10.00 P.M. and 05.00 A.M. (36.8\%). Less than half of respondents claimed to be free from work on Sundays $(47.6 \%)$. Slightly more than a third were free from work on Saturdays $(35.4 \%)$. About one in three health professionals disclosed that they were asked at least once a month to work more than $10 \mathrm{~h} \mathrm{a}$ day $(36.7 \%)$. Besides this, a quarter of the sample reported that they had less than $11 \mathrm{~h}$ between two consecutive working days at least once a month (27.1\%).

In general, the respondents were satisfied with their involvement in organizational and managerial dynamics $(\mu=3.09 ; \sigma=0.91 ; \min =1 ; \max =5)$. More than a forth stated that they experienced only a limited degree of involvement in taking a decision over issues that were related to their work $(25.8 \%)$. Conversely, about one in five people disclosed a strong degree of involvement $(18.5 \%)$. The sample showed, on average, acceptable levels of work life balance $(\mu=3.80 ; \sigma=0.71 ; \min =1 ; \max =5)$. Nevertheless, only 1 in 15 health professionals reported an excellent ability to handle the work-life interplay (6.5\%).

The employee-manager relationships were self-assessed as fair and adequate by the sample $(\mu=3.95 ; \sigma=0.92 ; \min =1 ; \max =5)$. Notwithstanding, more than 1 in 10 health professionals maintained to be unsatisfied with the quality of relationship established with their supervisor $(11 \%)$. Lastly, yet importantly, respondents perceived, on average, a good organizational climate $(\mu=3.95$; $\sigma=0.92 ; \min =1 ; \max =5)$. Nonetheless, a non-negligible part of respondents experienced either a poor $(3.5 \%)$ or a neutral $(7.6 \%)$ organizational climate.

Table 4 reports the findings of a serial mediation model investigating the direct and indirect effects of EI on WLB without including any control variable. The involvement of health professionals in work-related decisions was found to have a negative direct effect on work-life balance, impairing their ability to handle the interface between work and life (Coeff. $=-0.0514$, statistically significant at the 0.05 level). Alternatively, employee-manager relationships were positively, but not significantly, related to WLB.

Table 4. The output of the serial mediation model without covariates.

\begin{tabular}{|c|c|c|c|c|c|c|}
\hline \multicolumn{7}{|c|}{ Outcome Variable: EM-R } \\
\hline \multicolumn{7}{|c|}{ Model summary } \\
\hline $\mathrm{R}$ & $R^{2}$ & MSE & $\mathrm{F}$ & df1 & df2 & $\mathrm{p}$ \\
\hline 0.3537 & 0.1251 & 0.7297 & 230. & 1 & 1614 & 0.0000 \\
\hline \multicolumn{7}{|c|}{ Model } \\
\hline & Coeff. & SE & $\mathrm{t}$ & $\mathrm{p}$ & LLCI & ULCI \\
\hline Constant & 28,234 & 0.0762 & 37.0287 & 0.0000 & 2.6738 & 2.9730 \\
\hline EI & $0.3587^{* * *}$ & 0.0236 & 15.1915 & 0.0000 & 0.3124 & 0.4051 \\
\hline \multicolumn{7}{|c|}{ Outcome variable: OC } \\
\hline \multicolumn{7}{|c|}{ Model summary } \\
\hline $\mathrm{R}$ & $R^{2}$ & MSE & $\mathrm{F}$ & df1 & df2 & $\mathrm{p}$ \\
\hline 0.6699 & 0.4487 & 0.3095 & 656.4999 & 2 & 1613 & 0.000 \\
\hline \multicolumn{7}{|l|}{ Model } \\
\hline & Coeff. & SE & $\mathrm{t}$ & $\mathrm{p}$ & LLCI & ULCI \\
\hline Constant & 1.6797 & 0.0675 & 24.8702 & 0.0000 & 1.5472 & 1.8122 \\
\hline EI & $0.0916^{* * *}$ & 0.0164 & 5.5689 & 0.0000 & 0.0593 & 0.1238 \\
\hline EM-R & $0.5110^{* * *}$ & 0.0162 & 31.5208 & 0.0000 & 0.4792 & 0.5428 \\
\hline
\end{tabular}


Table 4. Cont.

\begin{tabular}{|c|c|c|c|c|c|c|}
\hline \multicolumn{7}{|c|}{ Outcome variable: WLB } \\
\hline \multicolumn{7}{|c|}{ Model summary } \\
\hline $\mathrm{R}$ & $R^{2}$ & MSE & $\mathrm{F}$ & df1 & df2 & $\mathrm{p}$ \\
\hline 0.3181 & 0.1012 & 0.4581 & 60.486 & 3 & 1612 & 0.000 \\
\hline \multicolumn{7}{|l|}{ Model } \\
\hline & Coeff. & SE & $\mathrm{T}$ & $\mathrm{p}$ & LLCI & ULCI \\
\hline Constant & 2.6576 & 0.0966 & 27.4983 & 0.0000 & 2.4680 & 2.8472 \\
\hline EI & -0.0514 * & 0.0202 & -2.5462 & 0.0110 & -0.091 & -0.0118 \\
\hline EM-R & 0.0152 & 0.0251 & 0.6054 & 0.5450 & -0.0340 & 0.0644 \\
\hline OC & $0.3057^{* * *}$ & 0.0303 & 10.0907 & 0.0000 & 0.2463 & 0.3651 \\
\hline \multicolumn{7}{|c|}{ DIRECT AND INDIRECT EFFECTS OF WH ON WLB } \\
\hline \multicolumn{7}{|c|}{ Direct effect of EI on WLB } \\
\hline & Effect & SE & $\mathrm{t}$ & $\mathrm{p}$ & LLCI & ULCI \\
\hline & $-0.0514^{*}$ & 0.0202 & -2.5462 & 0.0110 & -0.0910 & -0.0118 \\
\hline \multicolumn{7}{|c|}{ Indirect effect of EI on WLB } \\
\hline & Effect & Boot SE & $\begin{array}{l}\text { Boot } \\
\text { LLCI }\end{array}$ & \multicolumn{2}{|c|}{ Boot ULCI } & \\
\hline Total & $0.0895 *$ & 0.0103 & 0.0705 & 0.1102 & & \\
\hline EI->EM-R->WLB & 0.0054 & 0.0099 & -0.0167 & 0.0248 & & \\
\hline EI->OC->WLB & $0.0280 *$ & 0.0063 & 0.0167 & 0.0411 & & \\
\hline EI->EM-R->OC $->$ WLB & $0.0560 *$ & 0.0074 & 0.0423 & 0.0717 & & \\
\hline
\end{tabular}

The organizational climate had a positive and significant effect on the health professionals' ability to deal with work-life balance (Coeff. $=0.3057$, statistically significant at the 0.001 level). It is worth noting that employees' involvement was positively and statistically related to both employee-manager relationships (Coeff. $=0.3587$, statistically significant at the 0.001 level) and organizational climate (Coeff. $=0.0916$, statistically significant at the 0.001 level). Besides, adequate employee-manager relationships were found to trigger a positive effect on the organizational climate (Coeff. $=0.5110$, statistically significant at the 0.001 level). Focusing on the indirect effects of EI on WLB, whilst EM-R did not act as a statistically significant mediator, OC positively and significantly mediated the relationship between employees' involvement and respondents work-life balance (effect $=0.0280$, significant at the 0.05 level). Moreover, a positive and statistically significant indirect effect between EI and WLB mediated by employee-manager relationships and organizational climate in sequence was retrieved (effect $=0.0560$, significant at the 0.05 level).

Table 5 shows the output of the expanded serial mediation model, which also included some control variables in statistical elaboration, such as respondents' gender, education, organizational age, type of employment, and working conditions. The inclusion of covariates did not significantly affect the direct and indirect implications of EI on WLB.

Table 5. The output of the serial mediation model with covariates.

\begin{tabular}{ccccccc}
\hline \multicolumn{10}{c}{ Outcome Variable: EM-R } \\
\hline $\mathrm{R}$ & $\mathrm{R}^{2}$ & MSE & $\mathrm{F}$ & $\mathrm{df1}$ & $\mathrm{df2}$ & $\mathrm{p}$ \\
0.3977 & 0.1582 & 0.7071 & 25.5383 & 11 & 1495 & 0.0000 \\
\hline
\end{tabular}


Table 5. Cont.

\begin{tabular}{|c|c|c|c|c|c|c|}
\hline \multicolumn{7}{|c|}{ Outcome Variable: EM-R } \\
\hline \multicolumn{7}{|c|}{ Model } \\
\hline & Coeff. & SE & $\mathrm{t}$ & $\mathrm{p}$ & LLCI & ULCI \\
\hline Constant & 3.0852 & 0.1152 & 26.7883 & 0.0000 & 2.8593 & 3.3111 \\
\hline EI & $0.3696^{* * *}$ & 0.0246 & 15.0347 & 0.0000 & 0.3214 & 0.4179 \\
\hline Gender (1 = Male) & -0.0881 & 0.0595 & -1.4798 & 0.1391 & -0.2048 & 0.0287 \\
\hline Education & -0.0532 & 0.0490 & -1.0859 & 0.2777 & -0.1492 & 0.0429 \\
\hline Sector Type (1 = Private) & $0.1024 *$ & 0.0503 & 2.0349 & 0.0420 & 0.0037 & 0.2011 \\
\hline Type of contract $(1=$ Unlimited $)$ & -0.1257 & 0.0753 & -1.6693 & 0.0953 & -0.2733 & 0.0220 \\
\hline Part-time employment & $-0.1292 *$ & 0.0527 & -2.4529 & 0.0143 & -0.2325 & -0.0259 \\
\hline Organizational age & $-0.0062^{* *}$ & 0.0022 & -2.7556 & 0.0059 & -0.0106 & -0.0018 \\
\hline Working at night & 0.1171 & 0.0610 & 1.9188 & 0.0552 & -0.0026 & 0.2368 \\
\hline Working on Sundays & $-0.1644^{*}$ & 0.0743 & -2.2110 & 0.0272 & -0.3102 & -0.0185 \\
\hline Working on Saturdays & 0.0786 & 0.0684 & 1.1480 & 0.2512 & -0.0577 & 0.2128 \\
\hline $\begin{array}{c}\text { Less than } 11 \mathrm{~h} \text { between } 2 \text { working } \\
\text { days }\end{array}$ & $-0.1881^{* * *}$ & 0.0497 & -3.7879 & 0.0002 & -0.2856 & -0.0907 \\
\hline \multicolumn{7}{|c|}{ Outcome variable: OC } \\
\hline \multicolumn{7}{|c|}{ Model summary } \\
\hline $\mathrm{R}$ & $\mathrm{R}^{2}$ & MSE & $\mathrm{F}$ & df1 & $\mathrm{df} 2$ & $\mathrm{p}$ \\
\hline 0.6843 & 0.4682 & 0.3013 & 109.6099 & 12 & 1494 & 0.000 \\
\hline \multicolumn{7}{|l|}{ Model } \\
\hline & Coeff. & SE & $\mathrm{t}$ & $\mathrm{p}$ & LLCI & ULCI \\
\hline Constant & 1.8350 & 0.0915 & 20.0624 & 0.0000 & 1.6556 & 2.0144 \\
\hline EI & $0.1008^{* * *}$ & 0.0172 & 5.8529 & 0.0000 & 0.0670 & 0.1346 \\
\hline EM-R & $0.4903^{* * *}$ & 0.0169 & 29.0411 & 0.0000 & 0.4572 & 0.5234 \\
\hline Gender (1 = Male) & -0.0041 & 0.0389 & -0.1062 & 0.9154 & -0.0804 & 0.0721 \\
\hline Education & $-0.1056^{* * *}$ & 0.0320 & -3.3037 & 0.0010 & -0.1683 & -0.0429 \\
\hline Sector Type (1 = Private) & $0.1349^{* * *}$ & 0.0329 & 4.1023 & 0.0000 & 0.0704 & 0.1994 \\
\hline Type of contract $(1=$ Unlimited $)$ & -0.0049 & 0.0492 & -0.1002 & 0.9202 & -0.1014 & 0.0916 \\
\hline Part-time employment & 0.0211 & 0.0344 & 0.6139 & 0.5394 & -0.0464 & 0.0887 \\
\hline Organizational age & 0.0003 & 0.0015 & 0.2270 & 0.8205 & -0.20025 & 0.0032 \\
\hline Working at night & -0.0070 & 0.0399 & -0.1754 & 0.8608 & -0.0852 & 0.0712 \\
\hline Working on Sundays & -0.0697 & 0.0486 & -1.4336 & 0.1519 & -0.1650 & 0.0257 \\
\hline Working on Saturdays & 0.0090 & 0.0447 & 0.2004 & 0.8412 & -0.0787 & 0.0966 \\
\hline $\begin{array}{l}\text { Less than } 11 \text { h between } 2 \text { working } \\
\text { days }\end{array}$ & $-0.1110^{* * *}$ & 0.0326 & -3.4059 & 0.0007 & -0.1749 & -0.0471 \\
\hline \multicolumn{7}{|c|}{ Outcome variable: WLB } \\
\hline \multicolumn{7}{|c|}{ Model summary } \\
\hline $\mathrm{R}$ & $R^{2}$ & MSE & $\mathrm{F}$ & df1 & $\mathrm{df} 2$ & $\mathrm{p}$ \\
\hline 0.3932 & 0.1546 & 0.4273 & 21.0047 & 13 & 1493 & 0.000 \\
\hline \multicolumn{7}{|l|}{ Model } \\
\hline & Coeff. & SE & $\mathrm{T}$ & $\mathrm{p}$ & LLCI & ULCI \\
\hline Constant & 2.7582 & 0.1227 & 22.4761 & 0.0000 & 2.5175 & 2.999 \\
\hline EI & -0.0416 * & 0.0207 & -2.0039 & 0.0453 & -0.0822 & -0.0009 \\
\hline EM-R & 0.0308 & 0.0251 & 1.2255 & 0.2206 & -0.0185 & 0.0801 \\
\hline OC & $0.2680^{* * *}$ & 0.0308 & 8.6988 & 0.0000 & 0.2076 & 0.3284 \\
\hline Gender (1 = Male) & $0.2142^{* * *}$ & 0.0463 & 4.6254 & 0.0000 & 0.1233 & 0.3050 \\
\hline Education & $0.0986^{* * *}$ & 0.0382 & -2.5814 & 0.0099 & -0.1736 & -0.0237 \\
\hline Sector Type ( $1=$ Private) & -0.0452 & 0.0394 & -1.1477 & 0.2513 & -0.1736 & -0.0237 \\
\hline Type of contract $(1=$ Unlimited $)$ & 0.1090 & 0.0586 & 1.8599 & 0.0631 & -0.0060 & 0.2239 \\
\hline Part-time employment & 0.0940 * & 0.0410 & 2.2909 & 0.0221 & 0.0135 & 0.1745 \\
\hline Organizational age & 0.0030 & 0.0017 & 1.7320 & 0.0835 & -0.0004 & 0.0065 \\
\hline Working at night & -0.0166 & 0.0475 & -0.3505 & 0.7260 & -0.1098 & 0.0765 \\
\hline Working on Sundays & -0.0494 & 0.0579 & -0.8524 & 0.3941 & -0.1630 & 0.0643 \\
\hline Working on Saturdays & -0.0791 & 0.0532 & -1.4852 & 0.1377 & -0.1835 & 0.0254 \\
\hline $\begin{array}{l}\text { Less than } 11 \mathrm{~h} \text { between } \\
2 \text { working days }\end{array}$ & $-0.1714^{* * *}$ & 0.0389 & -4.4018 & 0.0000 & -0.2478 & -0.0950 \\
\hline
\end{tabular}


Table 5. Cont.

\begin{tabular}{|c|c|c|c|c|c|c|}
\hline \multicolumn{7}{|c|}{ Direct and Indirect Effects of WH on WLB } \\
\hline \multicolumn{7}{|c|}{ Direct effect of EI on WLB } \\
\hline & Effect & SE & $\mathrm{t}$ & $\mathrm{p}$ & LLCI & ULCI \\
\hline & $-0.0416^{*}$ & 0.0207 & -2.0039 & 0.0453 & -0.0822 & -0.0009 \\
\hline \multicolumn{7}{|c|}{ Indirect effect of EI on WLB } \\
\hline & Effect & Boot SE & $\begin{array}{l}\text { Boot } \\
\text { LLCI }\end{array}$ & \multicolumn{2}{|c|}{ Boot ULCI } & \\
\hline Total & 0.0870 * & 0.0103 & 0.0675 & 0.1076 & & \\
\hline EI->EM-R->WLB & 0.0144 & 0.0100 & -0.0085 & 0.0303 & & \\
\hline $\mathrm{EI}->\mathrm{OC}->\mathrm{WLB}$ & $0.0270 *$ & 0.0059 & 0.0164 & 0.0392 & & \\
\hline EI $->$ EM-R $->$ OC $->$ WLB & 0.0486 * & 0.0073 & 0.0353 & 0.0636 & & \\
\hline
\end{tabular}

The involvement of employees continued to be negatively and significantly related to the individual ability to manage the work-life interplay (Coeff. $=-0.0416$, significant at the 0.05 level). Whilst EM-R was positively, but not significantly associated with WLB, a positive organizational climate implied increased abilities of respondents to deal with overlapping work and family commitments (Coeff. $=0.2680$, significant at the 0.001 level). Men, those with higher education levels, part-time employees, and people who were less likely to report less than $11 \mathrm{~h}$ between two working days had better work-life balance. Both employees' involvement (Coeff. $=0.1008$, significant at the 0.001 level) and adequate employee-manager relations (Coeff. $=0.4903$, significant at the 0.001 level) were found to positively and significantly affect the organizational climate. In addition, EI implied the establishment of positive employee-manager relationships (Coeff. $=0.3696$, significant at the 0.001 level). On the one hand, health professionals employed in the private sector had better experiences of organizational climate, whilst people with better education and those who were reported to have less than $11 \mathrm{~h}$ between two consecutive working days at least once a week were more likely to suffer from an endangered organizational climate. On the other hand, full-time employees and those working for private sector organizations disclosed better EM-R.

Even after taking into consideration covariates, the direct effect of employees' involvement on work-life balance was negative and statistically significant. However, the total indirect effect of EI on WLB as serially mediated by EM-R and OC was positive and statistically significant. It is interesting to note that employee-manager relationships did not act as a significant single mediator of the relationship between employees' involvement and work-life balance. Conversely, organizational climate was found to perform as a positive and statistically significant single mediator between EI and WLB, triggering an amelioration of the employees' ability to manage the interplay between their work and life commitments.

\section{Discussion}

Figure 3 graphically summarizes the output of the serial mediation analysis, which was designed to collect evidence on the direct and indirect implications of employees' involvement on individual work-life balance. Drawing on the study findings, Table 6 reports the results of the hypotheses testing. 


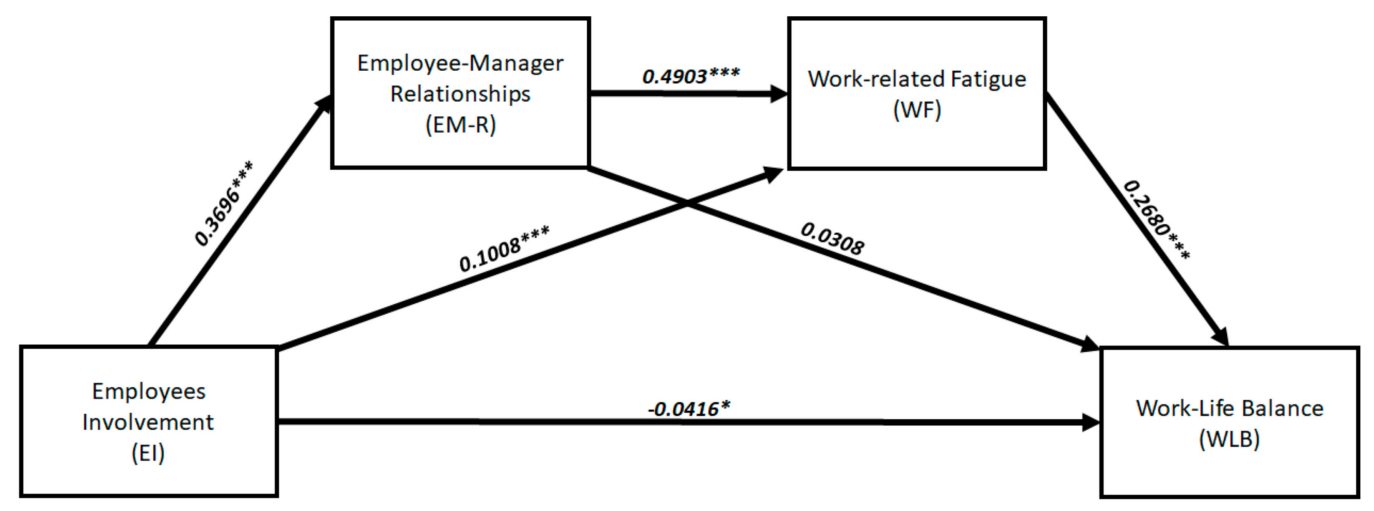

$c^{\prime}=$ Direct effect of $\mathrm{El}$ on WLB $=-0.2341$

$a_{1}{ }^{*} b_{1}=$ Indirect effect of EI on WLB through EM-R $=0.0144$

$a_{2}{ }^{*} b_{2}=$ Indirect effect of El on WLB through OC $=0.0270 *$

$a_{1}{ }^{*} d_{21}{ }^{*} b_{2}=$ Indirect effect of El on WLB through EM-R and OC in serial $=0.0486 *$

Figure 3. A graphical overview of the study findings. ${ }^{*}=$ significant at the 0.05 level; ${ }^{* * *}=$ significant at the 0.001 level.

Table 6. The results of the hypotheses testing.

\begin{tabular}{|c|c|c|}
\hline \# Hypothesis & Contents & Result \\
\hline $\mathrm{H} 1$ & $\begin{array}{l}\text { Employees' involvement may have some negative effects on } \\
\text { the workforce's ability to handle the work-life interface, due } \\
\text { to increased occurrence of work intensification }\end{array}$ & Supported \\
\hline $\mathrm{H} 2$ & $\begin{array}{l}\text { Employees' involvement enhances the employee-manager } \\
\text { relationships, boosting the establishment of positive } \\
\text { exchanges }\end{array}$ & Supported \\
\hline H3 & $\begin{array}{c}\text { Employees' involvement contributes to the amelioration of } \\
\text { the organizational climate, sustaining a sense of fairness, } \\
\text { trust, and collaboration in the workplace }\end{array}$ & Supported \\
\hline $\mathrm{H} 4$ & $\begin{array}{l}\text { Better employee-manager relationships foster an } \\
\text { improvement of the organizational climate, paving the way } \\
\text { for an aggregating working environment }\end{array}$ & Supported \\
\hline H5 & $\begin{array}{l}\text { Better employee-manager relationships contributes to the } \\
\text { improvement of the employees' perception about their } \\
\text { ability to manage the work-life interplay }\end{array}$ & Not supported \\
\hline H6 & $\begin{array}{l}\text { Positive organizational climate sustains the employees' } \\
\text { perception of work-life balance }\end{array}$ & Supported \\
\hline H7 & $\begin{array}{c}\text { Employee-manager relationships mediate the implications } \\
\text { of employees' involvement on work-life balance, so that the } \\
\text { employees' perceptions of managing the work-life interplay } \\
\text { are better }\end{array}$ & Not supported \\
\hline H8 & $\begin{array}{c}\text { A positive organizational climate mediates the implications } \\
\text { of employees' involvement on work-life balance, so that the } \\
\text { employees' perceptions of managing the work-life interplay } \\
\text { are better }\end{array}$ & Supported \\
\hline H9 & $\begin{array}{c}\text { Employee-manager relationships and organizational climate } \\
\text { serially mediate the implications of employees' involvement } \\
\text { on work-life balance, so that the employees' perceptions of } \\
\text { managing the work-life interplay are better }\end{array}$ & Supported \\
\hline
\end{tabular}

As forecasted by Hypothesis 1, health professionals' involvement was found to have a backlash on individual work-life balance. As argued in previous research, the increased involvement of employees in addressing organizational and managerial challenges may pave the way for work intensification and emotional exhaustion [71], which determine side effects on the individual ability to handle the work-life interplay [72]. This is especially true for people working in the service sector, such as health professionals and health associate professionals, whose burdensome job may be not consistent with 
the demanding commitments raised by their increased involvement in addressing organizational and managerial dynamics related to their work [73]. Inadequate attention paid to the drawbacks of employees' involvement on work-life balance may hamper the contribution of these interventions on the enhancement of organizational sustainability [20].

Health professionals' involvement had a positive effect on the employee-manager relationship, as assumed in Hypothesis 2. In fact, health professionals who reported a greater involvement in work-related decision-making stated a better social exchange with their supervisors. This may be produced by the perception of empowerment triggered by the implementation of involvement initiatives, which fosters an amelioration of interpersonal relationships at work [74]. Moreover, it is the outcome of a stronger work-related engagement of involved employees, which boosts their willingness to commit high levels of energy to support managers in dealing with the challenges that put the organizational effectiveness under stress [75].

As depicted in Hypothesis 3, work involvement concurred in increasing the organizational climate experienced by health professionals. Involvement acts as a catalyst to the adoption of organizational citizenship behaviors [76], which nurture loyalty, fairness, and collaboration in the workplace, thus paving the way for the establishment of a positive working environment [77]. It is worth noting that, as anticipated by Hypothesis 4, adequate employee-manager relationship implied good sensations with the organizational climate. On the one hand, improved social exchanges between employees and supervisors entailed greater levels of trust and commitment in the workplace, increasing the perceived quality of the working environment [78]. On the other hand, positive employee-manager relationships sustain the organizational commitment and the engagement of employees in organizational dynamics, thus enhancing the perceived organizational climate [79].

Interestingly, Hypothesis 5 was not supported-sound employee-manager relationships were positively, but not significantly associated with an increased ability of employees to manage the work-life interplay. This finding suggests that the amelioration of employee-manager exchanges is not conducive to better outcomes in terms of work-life balance. Rather, it can bring about an over-identification of employees with managers, which may generate an intensification of work due to a greater commitment and participation in addressing organizational dynamics. Sticking to these considerations, the improvement of employee-manager relationships should be supported by tailored organizational interventions aimed at enriching the individual ability to manage the work-life interface [80]. Conversely, the quality of the organizational climate perceived by health professionals was positively and significantly associated with their work-life balance, thus supporting Hypothesis 6. A supportive working environment based on trust, collaboration, and fairness may increase the respondents' ability to escape both work-to-life and life-to-work conflicts, thus advancing the internal organizational sustainability [81].

Collected evidence did not support Hypothesis 7. Employee-manager relationships were not found to mediate the implications of employees' involvement on work-life balance. However, Hypothesis 8 was confirmed, with organizational climate performing as a positive and significant mediator of the relationship between employees' involvement and work-life balance. The research findings pointed out the existence of a positive and statistically significant indirect effect of employees' involvement on work-life balance, serially mediated by employee-manager relationships and organizational climate, thus upholding Hypothesis 9. The total indirect effect of health professionals' involvement on work-life balance was positive, with enhanced employee-manager social exchanges and improved organizational climate being able to overcome the negative direct effects of employees' involvement interventions on the employees' ability to handle the interplay between work and life.

Several limitations affected this study. The acknowledgement of these allows us to better emphasize the conceptual and practical implications of this research. Firstly, the cross-sectional nature of the dataset prevented us from obtaining consistent and dependable evidence about the longitudinal effects of employees' involvement on work-life balance. Further developments should be intended to shed light onto the lengthwise interaction between these two phenomena, strengthening the reliability 
of the empirical evidence presented above. Secondly, only health professionals and health associate professionals participated in this study. This focus did not allow us to have a comprehensive account of the implications of involvement initiatives for other categories of employees working for healthcare organizations, such as administrative clerks. Future research should be intended to obtain some insights into the outcomes of employees' involvement targeted to the different categories of people who operate in the healthcare sector, comparing their behaviors with those displayed by the health professionals. Thirdly, and lastly, the use of secondary data prevented us from targeting the process of data collection to the specific purposes of this research. Nevertheless, the sixth EWCS was a reliable and consistent source of information, which was fully consistent with the aims of this research.

The contribution of this research is twofold. From a conceptual point of view, it proposes a critical interpretation of health professionals' involvement as a management tool, which may trigger an improvement of internal sustainability of healthcare organizations. Implying a sharpening of the work-related demands faced by health professionals, involvement initiatives may have some side effects on their ability to cope with the interplay between work and life. Since the ability to accommodate the work-life balance of employees is a critical component of internal sustainability $[82,83]$, failure to account for this issue and to address the drawbacks of employees' involvement on the individual ability to handle the work-life interplay does not allow for the achievement of organizational viability.

From a practical perspective, the research findings suggest that, to contribute to the enhancement of organizational sustainability, health professionals' involvement should be accompanied by an effort to increase the meaningfulness of the relationship between employees and supervisors and to enhance the quality of the organizational climate. Positive employee-manager relationships act as a buffer to the extensification and the intensification of work triggered by involvement interventions, enabling managers to enrich the work-life arrangements proposed to health professionals. Moreover, a positive organizational climate underpins the values of fairness, trust, loyalty, and cooperation, which are essential to prevent the side effects of health professional involvement initiatives in terms of effort intensification and contamination between work commitments and everyday life.

\section{Conclusions}

Internal organizational sustainability is a key ingredient of the recipe for the long-term viability of healthcare organizations. Human resource management practices aimed at empowering health professionals are fundamental to achieve internal organizational sustainability. Among others, health professional involvement interventions have been considered to be the cornerstone of organizational sustainability, paving the way for valuable gains in terms of organizational commitment and participation. However, the involvement of employees into organizational dynamics and managerial issues may produce some drawbacks on individual work-life balance. Triggering an extensification of work and an intensification of efforts, health professionals' involvement brings with itself increased risks of contamination between work-related commitments and everyday life, thus heralding both work-to-life and life-to-work conflict. This is especially relevant when involved employees are concerned by burdensome work demands, as it usually happens in the healthcare sector.

The side effects of health professionals' involvement on the individual work-life balance may compromise the positive implications of these initiatives on organizational sustainability, putting the well-being of employees under stress. Two tailored interventions should accompany health professionals' involvement in an attempt to avoid these shortcomings. Firstly, involvement of health professionals should be supported by an amelioration of the employee-manager social exchanges, enabling the latter to act as buffers to the phenomena of work intensification and extensification that may be experienced by the former. Secondly, the establishment of an organizational climate based on loyalty, fairness, and collaboration is crucial to minimize the risk that that health professionals' involvement is exploited as a subtle strategy by top and middle managers to load their organizational responsibilities on the shoulders of employees. The involvement of health professionals' in synergy with the promotion of sound employee-manager relationships and with the enactment of a meaningful 
organizational climate is expected to contribute in the empowerment of health professionals and to set the conditions for a viable internal sustainability.

Funding: This research received no external funding

Conflicts of Interest: The author declares no conflict of interest.

\section{References}

1. Borgonovi, E.; Compagni, A. Sustaining Universal Health Coverage: The Interaction of Social, Political, and Economic Sustainability. Value Health 2013, 16, 34-38. [CrossRef]

2. Podein, R.J.; Hernke, M.T. Integrating Sustainability and Health Care. Prim. Care 2010, 37, 137-147. [CrossRef] [PubMed]

3. Borgonovi, E.; Adinolfi, P.; Palumbo, R.; Piscopo, G. Framing the Shades of Sustainability in Health Care: Pitfalls and Perspectives from Western EU Countries. Sustainability 2018, 10, 4439. [CrossRef]

4. Bhatia, V.; Orsini, M. Narrating Sustainability in Canadian Health Care Reform Discourse. Soc. Pol. Adm. 2016, 50, 297-315. [CrossRef]

5. Harris, C.; Green, S.; Ramsey, W.; Allen, K.; King, R. Sustainability in Health care by allocating resources effectively (SHARE) 1: Introducing a series of papers reporting an investigation of disinvestment in a local healthcare setting. BMC Health Serv. Res. 2017, 17, 323. [CrossRef] [PubMed]

6. Gruen, R.L.; Elliott, J.H.; Nolan, M.L.; Lawton, P.D.; Parkhill, A.; McLaren, C.J.; Lavis, J.N. Sustainability science: An integrated approach for health-programme planning. Lancet 2008, 372, 1579-1589. [CrossRef]

7. Pammolli, F.; Riccaboni, M.; Magazzini, L. The sustainability of European health care systems: Beyond income and aging. Eur. J. Health Econ. 2012, 13, 623-634. [CrossRef]

8. Kaplan, S.B.; Forst, L. Linking Environmental Sustainability, Health, and Safety Data in Health Care: A Research Roadmap. New Solut. 2017, 27, 189-209. [CrossRef] [PubMed]

9. Garcés, J.; Ródenas, F; Sanjosé, V. Towards a new welfare state: The social sustainability principle and health care strategies. Health Pol. 2003, 65, 201-215. [CrossRef]

10. Bethencourt, C.; Galasso, V. Political complements in the welfare state: Health care and social security. J. Public Econ. 2008, 92, 609-632. [CrossRef]

11. Lyons, G.J.; Duggan, J. System dynamics modelling to support policy analysis for sustainable health care. J. Simul. 2015, 9, 129-139. [CrossRef]

12. Lega, F.; Prenestini, A.; Spurgeon, P. Is Management Essential to Improving the Performance and Sustainability of Health Care Systems and Organizations? A Systematic Review and a Roadmap for Future Studies. Value Health 2013, 16, 46-51. [CrossRef] [PubMed]

13. Olsen, I.T. Sustainability of Health Care: A Framework for Analysis. Health Policy Plan. 1998, 13, 287-295. [CrossRef] [PubMed]

14. Moore, J.E.; Mascarenhas, A.; Bain, J.; Straus, S.E. Developing a comprehensive definition of sustainability. Implement. Sci. 2017, 12, 110. [CrossRef]

15. Palumbo, R.; Annarumma, C.; Musella, M. Exploring the meaningfulness of healthcare organizations: A multiple case study. Int. J. Public Sect. Manag. 2017, 30, 503-518. [CrossRef]

16. Mosadeghrad, M.A. Obstacles to TQM success in health care systems. Int. J. Health Care Qual. Assur. 2013, 26, 147-173. [CrossRef] [PubMed]

17. Mackie, K.S.; Holahan, C.K.; Gottlieb, N.H. Employee Involvement Management Practices, Work Stress, and Depression in Employees of a Human Services Residential Care Facility. Hum. Relat. 2001, 54, 1065-1092. [CrossRef]

18. Welikala, D.; Sohal, A.S. Total Quality Management and employees' involvement: A case study of an Australian organisation. Total Qual. Manag. 2008, 19, 627-642. [CrossRef]

19. Zatzick, C.D.; Iverson, R.D. Putting employee involvement in context: A cross-level model examining job satisfaction and absenteeism in high-involvement work systems. Int. J. Hum. Resour. Manag. 2011, 22, 3462-3476. [CrossRef]

20. Kossek, E.E.; Valcour, M.; Lirio, P. The sustainable workforce: Organizational strategies for promoting work-life balance and wellbeing. In Wellbeing: A Complete Reference Guide. Work and Wellbeing; Chen, P.Y., Cooper, C.L., Eds.; Wiley Blackwell: Hoboken, NJ, USA, 2014; pp. 295-318. 
21. Mushfiqur, R.; Mordi, C.; Oruh, E.S.; Nwagbara, U.; Mordi, T.; Turner, I.M. The impacts of work-life-balance (WLB) challenges on social sustainability: The experience of Nigerian female medical doctors. Empl. Relat. 2018, 40, 868-888. [CrossRef]

22. Chu, K.W.K.; Cheung, L.L.W. Incorporating sustainability in small health-care facilities: An integrated model. Leasdersh Health Serv. 2018, 31, 441-451. [CrossRef]

23. Kalliath, T.; Brough, P. Work-life balance: A review of the meaning of the balance construct. J. Manag. Organ. 2008, 14, 323-327. [CrossRef]

24. Wood, S. HRM, organizational performance and employee involvement. In Comparative Employment Relations in the Global Economy; Frege, C., Kelly, J., Eds.; Taylor \& Francis: London, UK, 2013; pp. 89-107.

25. Tian, A.W.; Gamble, J. Challenged and satisfied: The role of organisational ownership and employee involvement. Int. J. Hum. Resour. Manag. 2018, 29, 2780-2803. [CrossRef]

26. Engström, A.K.; Rosengren, K.; Hallberg, L.R.M. Balancing involvement: employees' experiences of merging hospitals in Sweden. J. Adv. Nurs. 2002, 38, 11-18. [CrossRef]

27. Lee, E.K.; Hong, W.; Avgar, A.C. Containing conflict: A relational approach to the study of high-involvement work practices in the health-care setting. Int. J. Hum. Resour. Manag. 2015, 26, 100-122. [CrossRef]

28. Mosadegh, M.R.A.; Yarmohammadian, H.M. A study of relationship between managers' leadership style and employees' job satisfaction. Leadersh Health Serv. 2006, 19, 11-28.

29. Wilkinson, A.; Marchington, M.; Goodman, J.; Ackers, P. Total Quality Management and Employee Involvement. Hum. Resour. Manag. J. 1992, 2, 1-20. [CrossRef]

30. Riordan, C.M.; Vandenberg, R.J.; Richardson, H.A. Employee involvement climate and organizational effectiveness. Hum. Resour. Manag. 2005, 44, 471-488. [CrossRef]

31. Wallace, J.C.; Butts, M.M.; Johnson, P.D.; Stevens, F.G.; Smith, M.B. A Multilevel Model of Employee Innovation. J. Manag. 2013, 42, 982-1004. [CrossRef]

32. Brown, M.; Cregan, C. Organizational change cynicism: The role of employee involvement. Hum. Resour. Manag. 2008, 47, 667-686. [CrossRef]

33. Cox, A.; Zagelmeyer, S.; Marchington, M. Embedding employee involvement and participation at work. Hum. Resour. Manag. J. 2006, 16, 250-267. [CrossRef]

34. Wilkinson, A.; Godfrey, G.; Marchington, M. Bouquets, Brickbats and Blinkers: Total Quality Management and Employee Involvement in Practice. Organ. Stud. 1997, 18, 799-819. [CrossRef]

35. Smith, V. Employee Involvement, Involved Employees: Participative Work Arrangements in a White-Collar Service Occupation. Soc. Probl. 1996, 43, 166-179. [CrossRef]

36. Wilkinson, A.; Townsend, K.; Burgess, J. Reassessing employee involvement and participation: Atrophy, reinvigoration and patchwork in Australian workplaces. J. Ind. Relat. 2013, 55, 583-600. [CrossRef]

37. Juravich, T.; Harris, H.; Brooks, A. Mutual gains? labor and management evaluate their employee involvement programs. J. Labor Res. 1993, 14, 165-185. [CrossRef]

38. Lever-Tracy, C. Fordism Transformed? Employee Involvement and Workplace Industrial Relations at Ford. J. Ind. Relat. 1990, 32, 179-196. [CrossRef]

39. Juravich, T. Empirical Research on Employee Involvement: A Critical Review for Labor. Lab. Stud. J. 1996, 21, 51-69.

40. MacKy, K.; Boxall, P. High-involvement work processes, work intensification and employee well-being: A study of New Zealand worker experiences. Asia Pac. J. Hum. Resour. 2008, 46, 38-55. [CrossRef]

41. Le Fevre, M.; Boxall, P.; Macky, K. Which workers are more vulnerable to work intensification? An analysis of two national surveys. Int. J. Manpow. 2015, 36, 966-983. [CrossRef]

42. Schoneboom, A. It makes you make the time: 'Obligatory' leisure, work intensification and allotment gardening. Ethnography 2018, 19, 360-378. [CrossRef]

43. Fenton-O'Creevy, M. Employee involvement and the middle manager: Evidence from a survey of organizations. J. Organ. Behav. 1998, 19, 67-84. [CrossRef]

44. Kaufman, B.E. High-level employee involvement at Delta Air Lines. Hum. Resour. Manag. 2003, 42, 175-190. [CrossRef]

45. Brad Shuck, M.; Rocco, T.S.; Albornoz, C.A. Exploring employee engagement from the employee perspective: Implications for HRD. J. Eur. Ind. Train. 2011, 35, 300-325. [CrossRef]

46. Min, M.; Zhu, Y.; Bambacas, M. Implementing HPWS among the indigenous companies in China: Analysing from both managers' and employees' perspectives. J. Gen. Manag. 2018, 43, 175-187. [CrossRef] 
47. Sipa, M. The Factors Determining the Creativity of the Human Capital in the Conditions of Sustainable Development. Eur. J. Sustain. Develop. 2018, 7, 1-13. [CrossRef]

48. Ulhassan, W.M.; Von Thiele Schwarz, U.; Thor, J.; Westerlund, H. Interactions between lean management and the psychosocial work environment in a hospital setting-A multi-method study. BMC Health Serv. Res. 2014, 14, 480. [CrossRef]

49. Lin, W.B. The exploration of employee involvement model. Expert Syst. Appl. 2006, 31, 69-82. [CrossRef]

50. Schreurs, B.; Guenter, H.; Schumacher, D.; Van Emmerik, I.H.; Notelaers, G. Pay-Level satisfaction and employee outcomes: The Moderating effect of employee-involvement climate. Hum. Resour. Manag. 2013, 52, 399-421. [CrossRef]

51. Koene, B.A.S.; Vogelaar, A.L.W.; Soeters, J.L. Leadership effects on organizational climate and financial performance: Local leadership effect in chain organizations. Leadersh Q. 2002, 13, 193-215. [CrossRef]

52. Gould-Williams, J. HR practices, organizational climate and employee outcomes: Evaluating social exchange relationships in local government. Int. J. Hum. Resour. Manag. 2007, 18, 1627-1647. [CrossRef]

53. Stavrou, E.; Ierodiakonou, C. Entitlement to Work-Life Balance Support: Employee/Manager Perceptual Discrepancies and Their Effect on Outcomes. Hum. Resour. Manag. 2016, 55, 845-869. [CrossRef]

54. Gabler, C.B.; Hill, R.P. Abusive supervision, distributive justice, and work-life balance: Perspectives from salespeople and managers. J. Pers. Sell. Sale Manag. 2015, 35, 247-261. [CrossRef]

55. Grant, C.A.; Wallace, L.M.; Spurgeon, P.C. An exploration of the psychological factors affecting remote e-worker's job effectiveness, well-being and work-life balance. Empl. Relat. 2013, 35, 527-546. [CrossRef]

56. Thiruvenkadam, T.; Jayasingh, S. Determinants of employee happiness in an information technology company in India. Int. J. Eng. Technol. 2018, 7, 173-178.

57. Furnham, A. The People Business: Psychological Reflections on Management; Palgrave MacMillan: London, UK, 2005.

58. Karatepe, O.M. The effects of work overload and work-family conflict on job embeddedness and job performance: The mediation of emotional exhaustion. Int. J. Contemp. Hosp. Manag. 2013, 25, 614-634. [CrossRef]

59. Trauth, E.M.; Quesenberry, J.L.; Huang, H. Retaining women in the U.S. IT workforce: Theorizing the influence of organizational factors. Eur. J. Inf. Syst. 2009, 18, 476-497. [CrossRef]

60. Forstadt, L.; Fortune, A. Personal sustainability: Listening to extension staff and observing organizational culture. J. Ext. 2016, 54, 2RB1.

61. McCarthy, A.; Cleveland, J.N.; Hunter, S.; Darcy, C.; Grady, G. Employee work-life balance outcomes in Ireland: A multilevel investigation of supervisory support and perceived organizational support. Int. J. Hum. Resour. Manag. 2013, 24, 1257-1276. [CrossRef]

62. Han, S.J.; McLean, G.N. Effects of family-supportive supervisor behaviors and organizational climate on employees. Eur. J. Train. Dev. 2020, 44, 659-674. [CrossRef]

63. Yanadori, Y.; Van Jaarsveld, D.D. The Relationships of Informal High Performance Work Practices to Job Satisfaction and Workplace Profitability. Ind. Relat. 2014, 53, 501-534. [CrossRef]

64. Aragón-Correa, J.A.; Martín-Tapia, I.; Hurtado-Torres, N.E. Proactive Environmental Strategies and Employee Inclusion: The Positive Effects of Information Sharing and Promoting Collaboration and the Influence of Uncertainty. Organ. Environ. 2013, 26, 139-161. [CrossRef]

65. Hayes, A.F. Introduction to Mediation, Moderation, and Conditional Process Analysis: A Regression-Based Approach; Guilford Press: London, UK, 2018.

66. Netemeyer, R.G.; Bearden, W.O.; Sharma, S. Scaling Procedures: Issues and Applications; Sage Publications: London, UK, 2003.

67. Hayton, J.C.; Allen, D.G.; Scarpello, V. Factor Retention Decisions in Exploratory Factor Analysis: A Tutorial on Parallel Analysis. Organ. Res. Methods 2004, 7, 191-205. [CrossRef]

68. Kaiser, H.F. The application of electronic computers to factor analysis. Educ. Psychol. Meas. 1960, $20,141-151$. [CrossRef] 
69. Harrington, D. Confirmatory Factor Analysis; Oxford University Press: Oxford, UK, 2009.

70. Podsakoff, P.M.; MacKenzie, S.B.; Lee, J.Y.; Podsakoff, N.P. Common method biases in behavioral research: A critical review of the literature and recommended remedies. J. Appl. Psychol. 2003, 88, 879-903. [CrossRef]

71. Kloutsiniotis, P.V.; Mihail, D.M. Is it worth it? Linking perceived high-performance work systems and emotional exhaustion: The mediating role of job demands and job resources. Eur. Manag. J. 2020, 38, 565-579. [CrossRef]

72. Srivastava, A.K.; Chaturvedi, S. Negative Job Experiences and Employees Job Attitudes and Health in High-Performance Work Organizations. Metamorphosis 2014, 13, 22-28. [CrossRef]

73. Dahl-Jørgensen, C.; Saksvik, P.Ø. The Impact of Two Organizational Interventions on the Health of Service Sector Workers. Int. J. Health Serv. 2005, 35, 529-549. [CrossRef]

74. Liu, W. High-involvement human resource practices, employee learning and employability. Career Dev. Int. 2018, 23, 312-326. [CrossRef]

75. Oluwatayo, A.A.; Adetoro, O. Influence of Employee Attributes, Work Context and Human Resource Management Practices on Employee Job Engagement. Glob. J. Flex. Syst. Manag. 2020. [CrossRef]

76. Shweta, J.; Srirang, J. Determinants of Organizational Citizenship Behaviour: A Review of Literature. J. Manag. Public Pol. 2010, 1, 33-42.

77. Van Vianen, A.E.M.; De Pater, I.E.; Bechtoldt, M.N.; Evers, A. The strength and quality of climate perceptions. J. Manag. Psychol. 2011, 26, 77-92. [CrossRef]

78. Brandes, P.; Dharwadkar, R.; Wheatley, K. Social Exchanges Within Organizations and Work Outcomes: The Importance of Local and Global Relationships. Group Organ. Manag. 2004, 29, 276-301. [CrossRef]

79. Ahmad, I.; Donia, M.B.L.; Khan, A.; Waris, M. Do as I say and do as I do? The mediating role of psychological contract fulfillment in the relationship between ethical leadership and employee extra-role performance. Pers. Rev. 2019, 48, 98-117. [CrossRef]

80. Baral, R.; Bhargava, S. Work-family enrichment as a mediator between organizational interventions for work-life balance and job outcomes. J. Manag. Psychol. 2010, 25, 274-300. [CrossRef]

81. Burke, R.J. Organizational culture: A key to the success of work-life integration. In Work-Life Balance: A Psychological Perspective; Jones, F., Burke, R.J., Westman, M., Eds.; Psychology Press: London, UK, 2006; pp. 235-260.

82. Bertels, S.; Papania, L.; Papania, D. Embedding sustainability in organizational culture. In A Systematic Review of the Body of Knowledge; Ivey Business School, Network for Business Sustainability: London, UK, 2010.

83. Florea, L.; Cheung, Y.H.; Herndon, N.C. For All Good Reasons: Role of Values in Organizational Sustainability. J. Bus. Ethics. 2013, 114, 393-408. [CrossRef]

Publisher's Note: MDPI stays neutral with regard to jurisdictional claims in published maps and institutional affiliations.

(C) 2020 by the author. Licensee MDPI, Basel, Switzerland. This article is an open access article distributed under the terms and conditions of the Creative Commons Attribution (CC BY) license (http://creativecommons.org/licenses/by/4.0/). 